\title{
Cumulative Physiological Events Influence the Inflammatory Response of the Bovine Udder to Escherichia coli Infections During the Transition Period ${ }^{1}$
}

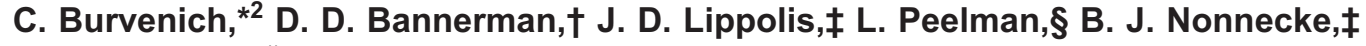 \\ M. E. Kehrli Jr.,\| and M. J. Paape† \\ *Ghent University, Faculty of Veterinary Medicine, Laboratory of Physiology, B9820 Merelbeke, Belgium \\ †Bovine Functional Genomics Laboratory, Beltsville Agriculture Research Center, USDA, ARS, Beltsville, MD 20705 \\ ¥Periparturient Diseases of Cattle Research Unit, National Animal Disease Center, USDA, ARS, Ames, IA 50010 \\ $\S$ Ghent University, Faculty of Veterinary Medicine, Laboratory of Genetics, B9820 Merelbeke, Belgium \\ ||Virus and Prion Diseases of Livestock Research Unit, National Animal Disease Center, USDA, ARS, Ames, IA 50010
}

\begin{abstract}
A high proportion of intramammary coliform infections present at parturition develop disease characterized by severe inflammatory signs and sepsis during the first 60 to $70 \mathrm{~d}$ of lactation. In the lactating bovine mammary gland, the innate immune system plays a critical role in determining the outcome of these infections. Since the beginning of the 1990s, research has increased significantly on bovine mammary innate defense mechanisms in connection with the pathogenesis of coliform mastitis. Neutrophils are key effector cells of the innate immune response to intramammary infection, and their function is influenced by many physiological events that occur during the transition period. Opportunistic infections occur when the integrity of the host immune system is compromised by physical and physiological conditions that make the host more susceptible. The innate immune system of many periparturient cows is immunocompromised. It is unlikely that periparturient immunosuppression is the result of a single physiological factor; more likely, several entities act in concert, with profound effects on the function of many organ systems of the periparturient dairy cow. Their defense system is unable to modulate the complex network of innate immune responses, leading to incomplete resolution of the pathogen and the inflammatory reaction. During the last $30 \mathrm{yr}$, most efforts have been focused on neutrophil diapedesis, phagocytosis, and bacterial killing. How these functions modulate the
\end{abstract}

\footnotetext{
Received October 22, 2006.

Accepted December 20, 2006.

${ }^{1}$ Presented at the ADSA-ASAS Joint Annual Meeting, Minneapolis, MN, July 2006. Disclaimer: Mention of trade names or commercial products in this article is solely for the purpose of providing specific information and does not imply recommendation or endorsement by the USDA or Ghent University.

${ }^{2}$ Corresponding author: christian.burvenich@ugent.be
}

clinical outcome of coliform mastitis, and how they can be influenced by hormones and metabolism has been the subject of intensive research and is the focus of this review. The afferent (sensing) arm of innate immunity, which enables host recognition of a diverse array of pathogens, is the subject of intense research interest and may contribute to the variable inflammatory response to intramammary infections during different stages of lactation. The development of novel interventions that modulate the inflammatory response or contribute to the elimination of the pathogen or both may offer therapeutic promise in the treatment of mastitis in periparturient cows.

Key words: Escherichia coli, periparturient, mastitis, cow

\section{INTRODUCTION}

Coliform pathogens are the single most common etiologic agent isolated from clinically severe mastitis cases on well-managed dairy farms (Anderson et al., 1982; Hogan et al., 1989). Clinical trials and experimental studies have repeatedly demonstrated no benefits of antibiotic therapy in cattle with clinical or subclinical coliform mastitis (Kirk and Barlett, 1984; Jones and Ward, 1990; Erskine et al., 1991). The advent of the Escherichia coli J-5 and other endotoxin core mutant vaccines in veterinary medicine has provided producers a tool to reduce the incidence and severity of clinical coliform mastitis (Gonzalez et al., 1989; Hogan et al., 1992). However, there still is an urgent need to seek new ways to prevent or treat coliform mastitis. This review details 1) the immune factors critical to successful defense of the bovine mammary gland against coliform bacteria; 2) physiological changes in the dairy cow that alter the ability of the immune system to provide effective protection against coliform mastitis; and 3) selected approaches taken by researchers to improve the resistance of dairy cows to coliform mastitis. 


\section{INNATE IMMUNITY IN THE BOVINE MAMMARY GLAND}

Innate immunity is the most universal and the most rapidly acting type of immunity (Beutler, 2004). In the lactating bovine mammary gland it is the most important defense system. The elimination of even one subset of innate immune effector cells (e.g., neutrophils) may be sufficient to cause a profound state of immunodeficiency (Jain et al., 1971).

Two aspects of innate immunity are important in the defense against intramammary $E$. coli infections: 1 ) the afferent (sensing) arm, which recognizes a diverse array of pathogens, and 2) the efferent (effector) arm, which kills these pathogens. Each arm is divided into cellular and humoral components, and the molecules that sense microbes are not necessarily the same as those that kill them. Effector cells are not absolutely required for all innate immune reactions. Proteins and other molecules are sufficient to kill microbes that have not yet been engulfed by cells (Beutler, 2004). Complement, lysozyme, lactoferrin, and antimicrobial peptides are among the proteins most commonly cited in this regard (Grün, 1985; Malinowski, 2002; Schmitz et al., 2004). There is no doubt that several innate immune proteins provide a measure of protection in the mammary gland cisterns. However, in the bovine udder the protective role of some of them seem to be unimportant (e.g., lysozyme). Furthermore, some of them have actions that depend on the stage of the lactation cycle (e.g., lactoferrin is only effective during steady-state involution in the absence of citrate; Smith and Schanbacher, 1977; Rejman et al., 1989).

In vertebrates, cellular innate immunity is largely dependent upon myeloid cells. Professional phagocytes engulf and destroy pathogens. The polymorphonuclear (PMN) phagocytes (which include neutrophils, basophils, and eosinophils) are of key importance in the containment of infection. In particular, neutrophils are specialized killers endowed with a broad array of weapons with which to destroy their microbial prey (Beutler, 2004). One of the major effector cells of the bovine innate immune system is the neutrophil, which has been extensively studied over the past $30 \mathrm{yr}$ (see reviews of Paape et al., 2000, 2002, 2003; Rainard and Riollet, 2006).

Neutrophils migrate from blood to the mammary gland in response to infection and constitute a major host defense mechanism (first-line defense; Paape et al., 2000). Protection is only effective if a rapid influx of neutrophils and subsequent phagocytosis and killing of bacteria occur (Paape et al., 2002, 2003). Neutrophils have stand-alone capabilities: They are capable of killing bacteria in vitro in the absence of serum factors
(Paape et al., 2000, 2002, 2003; Beutler, 2004). However, they have evolved to function optimally in conjunction with cells and proteins of the adaptive immune system. Antibodies produced by lymphoid cells of the adaptive immune system opsonize bacteria for destruction by neutrophils. The process of opsonization promotes the uptake of bacteria. Immunological recognition is mainly accomplished by specific antibodies $\left(\mathrm{IgG}_{2}\right.$ and IgM) that recognize the bacterium through Fabregions and bind to neutrophils via Fc-receptors on the neutrophil plasma membrane (Burvenich et al., 1994).

The incidence of mammary infections and the subsequent clinical reactions vary during the dry period (i.e., early and steady-state involution, and colostrogenesis) and early lactation.

\section{IMI DURING EARLY MAMMARY INVOLUTION}

Susceptibility of the mammary gland to new IMI is markedly increased during early involution (drying off; Oliver and Sordillo, 1988; Nickerson, 1989) and during the periparturient period (colostrogenesis; Smith et al., $1985 a, b)$. These periods coincide with unique local and systemic physiological phenomena that interrupt or induce lactation, when considerable changes in mammary tissue remodeling and nutritional demands occur.

A number of local phenomena contribute to the high incidence of new IMI during the early dry period. Milk, an excellent growth medium for bacteria, is no longer periodically removed from the gland, and leakage from the teats occurs because of the increase in intramammary pressure during the first days following dry off. Leukocytes, mainly phagocytes, start entering the gland by d 6 after dry off (McDonald and Anderson, 1981). The cell counts do not reach protective levels until d 8. An immunocompromised condition of these phagocytes is established through local factors. Indeed, after diapedesis, phagocytes start ingesting milk fat, $\mathrm{CN}$, and cell debris, which decreases phagocytic function and induces apoptosis. The citrate:lactoferrin ratio is very high, which makes any bacteriostatic action of lactoferrin ineffective. Milk citrate can effectively compete with lactoferrin for iron binding, and the resulting iron-citrate complex can be utilized by bacteria (Schanbacher et al., 1993).

\section{IMI DURING MAMMARY STEADY-STATE INVOLUTION}

In the cow, active involution is completed by 3 to 4 wk after drying off and is followed by a phase of steadystate involution. This is the period of greatest resistance to IMI, especially to gram-negative bacteria. If an infection occurs, it usually is spontaneously eliminated. This 
mid-dry period shows the lowest incidence of new infections because teats have become sealed, the fluid volume in the udder cisterns is low, and the composition of medium is unfavorable for bacterial growth. Very high concentrations of phagocytes are reached. The immunocompromised condition is suspended because there is practically no milk fat or $\mathrm{CN}$ that could inhibit phagocyte function.

Lactoferrin, the major protein found in mammary secretions during steady-state involution, reaches very high concentrations (Smith and Schanbacher, 1977; Rejman et al., 1989). The mechanism of lactoferrin activity has not been clearly defined but appears to originate primarily through sequestration of iron necessary for bacterial growth or through direct interaction of its cationic $N$-terminal region with bacterial components or both. Among the mastitis pathogens, $E$. coli are the most susceptible, followed by Staphylococcus aureus. Streptococci seem to be resistant (Rainard, 1986a). The citrate:lactoferrin ratio is lowered (because milk synthesis has stopped) and immunoglobulin concentrations are elevated. The bacteriostatic activity of lactoferrin can be enhanced by antibodies specific to mastitis-causing bacteria, possibly by interfering with the bacterial iron-acquisition systems (Rainard, 1986b; Oliver and Bushe, 1987).

\section{IMI DURING THE TRANSITION PERIOD}

Transition cows are referred to as cows in their second half of the dry period through 2 to 4 wk postpartum. Any physiological change from a pregnant, nonlactating status to a nonpregnant, lactating status represents a challenging period in the production cycle of a modern dairy cow. Most metabolic diseases of dairy cows such as milk fever and ketosis, and abomasal displacement occur within the first 2 wk of lactation.

From the second half of the transition period, and especially during colostrogenesis, cows become more susceptible to new intramammary bacterial infections (Smith et al., 1985b). The contribution of lactoferrin to protection of the mammary gland is compromised by its low concentration in milk and the presence of citrate. The phagocyte numbers not only decrease but their phagocytic capacity is also reduced again because of the appearance of fat and CN. However, during colostrogenesis, systemic factors also negatively affect the immune condition of the cow. In addition, the majority of infectious diseases experienced by the dairy cow also become clinically apparent during early lactation. This is especially the case for mastitis, but also includes diseases such as Johne's and salmonellosis.

A high proportion of intramammary coliform infections present at parturition develop disease character- ized by severe inflammatory signs and sepsis during the first 60 to 70 d of lactation (Malinowski et al., 1983; Smith et al., 1985a,b; Hogan et al., 1989). The clinical picture is reported as toxic mastitis and is very well known by veterinarians. Of those cows with severe gram-negative IMI, nearly $25 \%$ will either die or be culled. There is remarkable variability in the clinical expression and complications of coliform mastitis around parturition, ranging from clinically severe to moderate and mild (Hill et al., 1979; Hill, 1981; Heyneman et al., 1990; Vandeputte-Van Messom et al., 1993; Burvenich et al., 1994; Shuster et al., 1996; Hirvonen et al., 1999; Burvenich et al., 2003). This is in sharp contrast with the more moderate clinical expression of coliform mastitis during middle or late lactation (Burvenich et al., 1994; Shuster et al., 1996). Delays in the inflammatory response in cows with peracute coliform mastitis have been reported in certain cows shortly after calving (Hill et al., 1979; Hill, 1981; Heyneman et al., 1990; Vandeputte-Van Messom et al., 1993). The autotoxic character of the severe inflammatory response to infection falls in the category of sepsis. Bacterial sepsis and septic shock result from overproduction of inflammatory mediators as a consequence of the interaction of the immune system with bacteria and bacterial cell wall constituents in the body. Bacterial cell wall constituents such as LPS are particularly responsible for the deleterious effects of bacteria. These constituents interact in the body with a large number of proteins and receptors, and this interaction promotes the deleterious systemic inflammatory responses that can accompany $E$. coli IMI that occur during the periparturient period (van Amersfoort et al., 2003).

\section{COW PARITY AND SEVERITY OF CLINICAL E. COLI MASTITIS}

There is a tendency to see more severe clinical coliform mastitis cases in multiparous cows (van Werven et al., 1997; Mehrzad et al., 2001a,b, 2002; Burvenich et al., 2003; Vangroenweghe et al., 2004a,b). Blood neutrophil function is higher in younger animals than in cows after their fourth parturition. Also, the drop in the production of neutrophil reactive oxygen species (ROS) around parturition is more pronounced in multiparous cows (Mehrzad et al., 2002). The reduced ROS production and low viability of milk neutrophils of multiparous cows may be involved in the underlying mechanisms, making these animals more susceptible to periparturient infectious diseases. Moreover, white blood cell viability and oxidative burst have been found to be significantly different between primiparous cows and multiparous cows during the periparturient period. When high doses of $E$. coli inoculum were used, all primiparous 
cows reacted as moderate responders based on their quarter milk production in the noninfected quarter on $\mathrm{d}+2$ postinfection. On clinical severity scoring, all animals were scored as mild to moderate in their clinical response throughout the entire experimental challenge period (Vangroenweghe et al., 2004a,b).

\section{IMMUNOCOMPROMISATION DURING THE PERIPARTURIENT COW}

In 1989, it was hypothesized that an immunocompromised condition during the periparturient period existed that predisposes the dairy cow to new infections or the progression of subclinical mastitis into clinical disease or both (Kehrli et al., 1989a,b; Kehrli and Goff, 1989). A cause-and-effect relationship between a faltering innate and adaptive immune system and the development of IMI has been difficult to prove.

Circulating lymphocytes have reduced capacity to produce IFN- $\gamma$ (Ishikawa et al., 1994) and there are reduced IFN- $\gamma$ and IL-2 levels in lacteal secretions of periparturient cows (Sordillo et al., 1991). This immunocompromisation is most evident in the Th1 branch of lymphocyte activity, and may be essential in preventing unwanted immune reactions against self and paternal antigens exposed to the mother's immune system as a result of tissue damage in the reproductive tract during parturition. Lymphocytes exposed to $1 \alpha, 25$-dihydroxyvitamin $\mathrm{D}_{3}$ produce less IFN- $\gamma$ and IL-2, and more IL4, IL-5, and IL-10 (Daynes et al., 1996). The parturient surge in $1 \alpha, 25$-dihydroxyvitamin $\mathrm{D}_{3}$ may therefore contribute to the reduced capacity of bovine lymphocytes to produce IFN- $\gamma$ (Sordillo et al., 1991; Ametaj et al., 1996; Ametaj et al., 2000). Lymphocyte trafficking patterns also change in periparturient cows because the percentage of $\mathrm{T}$ cells declines from $\sim 45 \%$ of circulating lymphocytes in midlactation cows to $\sim 20 \%$ in periparturient cows (Shafer-Weaver et al., 1996).

The proportion of $\mathrm{CD}^{+}$cells in blood and mammary parenchyma also declines postpartum, which is consistent with decreased IFN- $\gamma$ secretion by lymphocytes and decreased IFN- $\gamma$ in lacteal secretions of periparturient cows (Sordillo et al., 1991; Ishikawa et al., 1994; Shafer-Weaver et al., 1996; Shafer-Weaver and Sordillo, 1997; Yang et al., 1997). The functional role of $\mathrm{CD}^{+}$lymphocytes during the postpartum period is most likely of an immunosuppressive nature, because IL-4 mRNA is the main cytokine detectable in mononuclear cells from postpartum dairy cows, whereas IFN$\gamma$ is the main cytokine detected from cows in middle to later stages of lactation (Shafer-Weaver and Sordillo, 1997).

In 1990, it was demonstrated that the severity of experimentally induced $E$. coli mastitis during the peri- parturient period was negatively correlated with a decreased production of ROS (Heyneman et al., 1990) and decreased chemotaxis (Lohuis et al., 1990) of isolated blood neutrophils. Later, this clinical severity was associated with levels of tumor necrosis factor- $\alpha$ (TNF- $\alpha$ ) produced as a consequence of endotoxin levels associated with the mastitis episode (Shuster et al., 1993; Shuster and Kehrli, 1995; Shuster et al., 1995, 1996, 1997; Blum et al., 2000).

Recently, Mehrzad et al. (2004) found that following experimental intramammary challenge of cows with $E$. coli, there was an inverse relationship between preinfection milk neutrophil ROS production and intramammary bacterial growth. In mild and moderately affected cows, the preinfection blood and milk neutrophil ROS production was $\sim 2$-fold higher than that of severely affected cows. The probability of severe disease increased with decreasing preinfection neutrophil function. Impairment of other neutrophil oxidative functions (e.g., oxidative metabolism and myeloperoxidase activity) immediately postpartum is a likely contributor to increased bacterial growth in severely diseased cows (Kehrli et al., 1989b; Kehrli and Goff, 1989; Cai et al., 1994; Detilleux et al., 1995).

The cow's udder is continuously challenged with bacteria from the environment and both have a high evolutionary degree of adaptation. Although $E$. coli mastitis can be a severe problem at the beginning of lactation, it is less severe and self-curing after peak lactation (Burvenich et al., 2004). Several systemic factors related to the stage of lactation and parity may contribute to functioning of the defense system in an abnormal or incomplete manner. For example, the activities of neutrophils in combating infection are complex and involve expenditure of cellular energy. The average cow has $\sim 3.5 \times 10^{6}$ neutrophils $/ \mathrm{mL}$ of blood; this translates into $\sim 1.4 \times 10^{11}$ neutrophils in an $800-\mathrm{kg}$ Holstein cow. The circulating half-life of neutrophils is about $6 \mathrm{~h}$ (Keane et al., 2006), so a cow is replacing half of its neutrophils every $6 \mathrm{~h}$ from bone marrow stores. Clearly, a component of dietary energy and protein consumption for maintenance is spent on replenishment of neutrophils by the bone marrow. Next to this, it is also known that there is considerable genetic control over the immune system capacity to function, especially around parturition (Detilleux et al., 1994, Detilleux, 2002, Paape et al., 2002). Therefore, a high milk yield will not likely dictate that a cow will experience a greater impact on its innate defense than a lower producing cow.

Conclusive evidence that the demands of lactation contribute to postpartum immune suppression derives from recent studies using mastectomized cows that were found to recover from periparturient immunosup- 
pression within 1 wk after calving, whereas intact lactating cows can be immunosuppressed for 2 to $3 \mathrm{wk}$ postpartum (Kimura et al., 1999a,b; Nonnecke et al., 2003). Negative energy and protein balances that exist during early lactation contribute to impaired immune function, and thus account for a portion of the periparturient immunosuppression observed.

Advances in proteomic techniques have allowed for the detection, identification, and quantitation of a large number of proteins simultaneously (Yates, 2004). These techniques have recently been applied to the study of the normal bovine neutrophil proteome, where it was found that the proteins present could be grouped into a few functional groups (Lippolis and Reinhardt, 2005). Nearly $35 \%$ of peptides identified were enzymes involved in basic cellular metabolic pathways. Proteins involved in cell structure and mobility or immune functions made up the next 2 most abundant groups of peptides, each representing approximately $15 \%$ of the total peptide spectra. Because circulating neutrophils have such a short half-life and a singular purpose, it is reasonable to find so much of the proteome dedicated to a few general functional groups. Circulating neutrophils are poised to respond to inflammation very quickly. To provide host defense efficiently, appropriate metabolic enzymes required for the primary functions of the neutrophil would already be made abundantly. Consistent with that hypothesis, the majority of the enzymes involved in the pentose phosphate pathway and gluconeogenesis, which are required for NADPH generation critical for a neutrophil oxidative burst, were present. In addition, most of the enzymes involved in glycolysis and the generation of ATP were found, which would provide the cellular energy necessary for transmigration into inflamed tissue. Thus, the proteome of the circulating neutrophil appears to be constantly in a state of readiness for eliciting a respiratory burst of oxidative metabolism to support phagocytosis.

To further our understanding of neutrophil dysfunction in postpartum cows, mass spectrometry was also used to determine the relative protein expression from normal prepartum neutrophils and neutrophils isolated during immunosuppression at parturition (Lippolis et al., 2006a). Initial analysis of the bovine neutrophil proteome has determined a change in protein expression for nearly 300 proteins. Approximately 40 of the proteins identified had significant expression differences between the prepartum and the periparturient neutrophil proteomes. These data elucidate new and novel target areas for future studies of periparturient immunosuppression.

\section{HOW NEUTROPHILS NEUTRALIZE BACTERIA: EXTRACELLULAR TRAP FORMATION}

Neutrophils engulf and kill bacteria when their antimicrobial granules fuse with the phagosome. Upon acti- vation, neutrophils release granule proteins and chromatin that together form extracellular fibers that bind bacteria. These neutrophil extracellular traps (NET) degrade virulence factors and kill bacteria. The formation of NET seems be an important innate response. Antibacterial action has long been attributed to histones (Hirsch, 1958), and recently they have been shown to be part of nuclear material released from stimulated neutrophils. These NET have been shown to trap and facilitate the killing of bacteria (Brinkmann et al., 2004). Further support for bactericidal action of extruded DNA was provided by a study demonstrating that a bacterial strain with deletions of the genes encoding multiple DNases that are secreted by the bacteria was much less virulent than the wild-type strain (Sumby et al., 2005). This suggested that some bacteria have evolved immune escape mechanisms that function to destroy neutrophil NET. In addition to DNase, antibodies to the histones (H2A) have been shown to abrogate killing by NET (Brinkmann et al., 2004).

Down-regulation of a histone or its rearrangement in the cell may be a factor in periparturient neutrophil functional inhibition. Recent proteomic data in periparturient cows have shown that a specific histone (H2A.1) was down-regulated in neutrophil membranes from immunosuppressed animals, correlating with a period of decreased neutrophil function and increased disease susceptibility (Lippolis et al., 2006a). Thus, a potential link was created between neutrophil NET killing and periparturient immunosuppression. Other proteins shown to be differentially regulated during the periparturient period may also provide information about the mechanisms of immune suppression. 6-Phosphogluconate dehydrogenase, part of the hexose monophosphate shunt, was down-regulated in the periparturient cow. This enzyme has been shown to undergo a unique trafficking pattern in neutrophils of pregnant women (Kindzelskii et al., 2004). Because 6-phosphogluconate dehydrogenase is reduced or sequestered, the ability of neutrophils to generate NADPH may be reduced and the corresponding ability to generate ROS impaired. The utility of exploratory proteomics has been to link periparturient changes in the neutrophil proteome with a wide variety of proteins whose functions are being studied.

Bovine neutrophils have been shown to form NET in response to a variety of stimuli, including a bacterium common to clinical mastitis (Lippolis et al., 2006b). Importantly, bovine neutrophils are fully capable of forming NET in milk. The full capacity of neutrophils to generate NET in milk is in contrast with other neutrophil functions that are impaired by exposure of neutrophils to milk. Experiments with addition of $\mathrm{CN}$ to blood neutrophils showed that only a 5-min preincubation 
with CN resulted in reduced ROS generation following stimulation (Cooray, 1996). Furthermore, incubation of neutrophils in whole milk vs. skim milk, whey, or media resulted in neutrophils less able to ingest bacteria (Paape et al., 1975; Paape and Guidry, 1977). Because milk fat and proteins have been shown to be inhibitory to other antibacterial functions of the neutrophil (phagocytosis and oxidative burst), NET formation may play a central role in providing mammary gland health.

\section{HOW NEUTROPHILS NEUTRALIZE BACTERIA: FORMATION OF ROS}

Hydroxyl radicals, singlet oxygen, oxygen halides, hydrogen peroxide, and nitrogen oxide kill coliforms and are released during the process of phagocytosis into the phagolysosome and react with diverse molecular targets of the pathogen (lipids, proteins, and nucleic acids). In humans and in some other mammals, mutations affecting the generation of ROS (i.e., mutations of the components of NADPH oxidase, or myeloperoxidase) create severe immunodeficiencies, despite the presumed integrity of innate immune-signaling adaptive immune responses (Beutler, 2004). On the other hand, execessive production of ROS may cause substantial injury to healthy tissues. To minimize mammary tissue damage caused by bacterial toxins and ROS released by neutrophils, elimination of invading bacteria should proceed quickly. Therefore, the inflammatory response needs to be regulated. The concept of a wellbalanced inflammatory response, in which pro- and anti-inflammatory local mediators, such as cytokines, regulate the outcome of the inflammatory process, is also applicable to systemic factors. Hormones, metabolites, and acute phase proteins influence the outcome of mastitis. This is especially the case around parturition.

The worldwide consistency of findings on periparturient immunosuppression has been remarkable. For example, production of ROS by neutrophils isolated from blood was evaluated in several longitudinal studies in dairy cows from 3 wk before until 5 wk after calving, in the United States and in Europe. In all studies, a significant decrease in oxidative burst activity of neutrophils was observed. Interestingly, in the combined longitudinal US and European study of Dosogne et al. (1999), ingestion of bacteria and ROS production were inversely correlated. Although the phagocytic ingestion capacity increased during the $2 \mathrm{wk}$ before parturition, ROS levels were decreasing from 1 wk before parturition (Hoeben et al., 2000). Immature neutrophils cannot be held responsible for this inverse correlation, because they are not present in circulation prior to calving. Therefore, it might be hypothesized that the reduced ROS production of blood neutrophils around parturition underlies the selective depression of activation pathways involved in oxidative burst generation without affecting the ingestion capacity. Furthermore, the increased capacity for ingestion of pathogens by neutrophils may simply be a function of the fact that the cellular energy required to support the respiratory burst of oxidative metabolism is not used because of defects in that pathway, thus allowing neutrophils to deplete their energy stores by ingesting excessive numbers of bacteria.

\section{RATE OF NEUTROPHIL DIAPEDESIS IS CRITICAL FOR THE OUTCOME OF COLIFORM MASTITIS}

Neutrophils (and other leukocytes) roll along the surface of postcapillary venules at a far slower velocity than the blood flow. Rolling is maintained by contact between vascular and leukocyte surfaces (Burvenich et al., 1994; Diez-Fraile et al., 2002, 2003). Bovine leukocyte adhesion molecules such as L-selectin (CD62L) and the $\beta_{2}$-integrins play a key role in the initial contact and in the subsequent strong adhesion to postcapillary venules, respectively. In the bone marrow, L-selectin receptors are expressed at all granulocyte maturation stages. Bone marrow band and mature cells have the highest receptor density, even when compared with circulating neutrophils (Monfardini et al., 2004). Under conditions of inflammation, rolling becomes slower, leading to firm adhesion between the leukocyte and the venular wall. This is mediated by the upregulation of $\beta_{2}$-integrins and is the prelude to diapedesis, the process by which the neutrophil crosses the vascular barrier and follows a chemotactic gradient generated by the local tissue response to infection (Burvenich et al., 1994; Diez-Fraile et al., 2002, 2003).

Studies of periparturient cows during the first few hours after calving have revealed a transient loss of expression of critical neutrophil adhesion molecules (CD62L; Lee and Kehrli, 1998; Kimura et al., 1999a; Monfardini et al., 2002). The loss of CD62L on neutrophils after parturition is associated with elevated cortisol levels (Weber et al., 2001, 2004). Glucocorticoid administration to cattle is well documented to cause shedding of CD62L from neutrophils (Burton and Kehrli, 1995; Burton et al., 1995). The net effect of reduced neutrophil CD62L expression would be a transient loss in the efficiency of neutrophil immune surveillance and egress into infected tissues.

If a cow experiences a large demand for neutrophil egress into the uterus or mammary gland when immune surveillance is transiently impaired, a severe disease may occur as a result of a delayed inflammatory response. A delay in neutrophil arrival in lacteal secretions of just 20 min is not an insignificant effect, consid- 
ering that $E$. coli can double its numbers very fast (every 20 min in traditional media). A 1-h delay in neutrophil recruitment into the mammary gland could result in an 8-fold larger number of $E$. coli to kill and that much more endotoxin to detoxify. This delay in neutrophil recruitment has been reported in many studies (Hill et al., 1979; Hill, 1981; Heyneman et al., 1990; Vandeputte-Van Messom et al., 1993). Detilleux et al. (2006) estimated that more than $2 \times 10^{6}$ somatic cells $/ \mathrm{mL}$ are necessary to successfully fight an intramammary $E$. coli infection.

\section{ROLE OF ENDOTOXIN IN THE PATHOGENESIS OF E. COLI MASTITIS}

Endotoxin or LPS, the major constituent of the gramnegative bacterial cell wall, is released during bacterial growth and destruction and is implicated in the pathogenesis of gram-negative bacteria-induced mastitis. Lipopolysaccharide is a key molecule that contributes to both the localized and systemic inflammatory responses that accompany gram-negative bacterial-induced mastitis. The bovine mammary gland is highly sensitive to low doses of LPS (Carroll et al., 1964; Dhondt et al., 1977; Mattila and Frost, 1989) and injection of LPS into the mammary glands of healthy cows induces mastitis (Paape et al., 1974). Lipopolysaccharide is detectable in the milk of cows with coliform mastitis (Anri, 1989), and absorption into blood following naturally occurring and experimental E. coli mastitis (Katholm and Andersen, 1992; Dosogne et al., 2002) has been reported. Further, a significant proportion of cows with acute coliform mastitis develop bacteremia, thus introducing LPS directly into the circulation (Wenz et al., 2001). Neutrophils are involved in the clearance of both the pathogen and its LPS from the udder cavities. A factor contributing to the severity of coliform mastitis in postpartum cows is a reduction of acyloxyacyl hydrolase activity in circulating neutrophils (Dosogne et al., 1998). This enzyme is critical in detoxification of LPS (McDermott et al., 1991a,b).

Lipopolysaccharide, released during the growth phase of the pathogen in the teat and udder cistern, provokes host cells to produce large amounts of proinflammatory mediators by activating transcription factors. Transcription factors are DNA-binding proteins that regulate the expression of inflammatory genes, including enzymes involved in the synthesis of inflammatory mediators and protein and peptide mediators. Transcription factors therefore play a critical role in the expression of inflammatory proteins in mastitis, because many of these proteins are regulated at a transcriptional level. One target of LPS is nuclear factor $-\kappa \mathrm{B}$, a key regulator of immune and inflammatory responses.
Induction of nuclear factor- $\kappa \mathrm{B}$ transcriptional activity by LPS was observed in cells isolated from infected quarters (Boulanger et al., 2003).

Many proinflammatory mediators are released during coliform mastitis, such as IL-1, IL-6, IL-8, and TNF$\alpha$ (Shuster et al., 1996). These mediators may act synergistically to enhance each other's effects, or one mediator may modify the release or action of another mediator. Little is currently understood regarding these mediator interactions. However, it is likely that there are different mechanisms of inflammatory reactions among cows and that different patterns and quantities of inflammatory mediators may be involved (Massart-Leën et al., 1992). For example, the endotoxin-induced increase in cortisol during clinical mastitis (Massart-Leën et al., 1992) might be a homeostatic reaction (negative feedback) to down-regulate excessive proinflammatory cytokine production to avoid autointoxication (Blum et al., 2000). The development of mediator antagonists will greatly facilitate elucidation of such interactions and potentially offer new therapeutic options for treating mastitis in periparturient cows. Inhibition of the effects of TNF may be possible through the use of recombinant soluble forms of bovine TNF receptors (Mwangi et al., 2000; Taylor et al., 2002; Taylor et al., 2005) or as demonstrated by inhibition of p38 MAP kinase enzymatic pathways activated by TNF- $\alpha$ (Kehrli and Sakya, 2003).

\section{SENSING THE ENDOTOXIN TO DETECT MAMMARY E. COLI INFECTIONS}

To enable the host to orchestrate a balanced inflammatory reaction following an intramammary coliform infection, the pathogen has to be detected promptly. Here again, innate immune receptors must detect pathogen molecules within the infectious nidus before microbes proliferate, disseminate, and overwhelm the host (Beutler, 2004). Over the years, intraluminal $E$. coli sensing by "milk macrophages" and subsequent communication with the epithelium of the cistern of the mammary gland has been accepted as dogma. Details of the underlying mechanisms remained unknown and research was mainly focused on the interaction between the pathogen and the phagocyte, because it occurs during receptor-mediated and lectin phagocytosis (Burvenich et al., 1994). Generally, mucosal pathogens trigger a local innate host response by activating epithelial cells, and bacterial adherence signaling has been implicated as a key event in this process. However, because $E$. coli does not seem to colonize the mammary gland, as does Staph. aureus, the interaction between the $E$. coli and mammary epithelium received little attention (Burvenich et al., 2003). Yet since the detection of Toll- 
like receptors as evolutionarily conserved molecules and their role in innate defense, a new area of interest is now opened (Burvenich et al., 2000, 2004). The molecular machinery used by mammary innate immune cells as well as by the epithelial cells for the recognition of $E$. coli is now under investigation in several laboratories worldwide (Rainard and Riollet, 2006).

The mechanism of LPS sensing has immense practical importance. Endotoxins are elements of the pathogen associated molecular patterns and bind to patternrecognition receptors that are present on a variety of defense cells of the body. It is striking to see how a highly conserved molecule, such as LPS, is used by the host to recognize gram-negative pathogens and how at the same time this interaction may elicit an adverse immunopathologic effect on the host (Burvenich et al., 2004).

Cellular recognition of LPS is mediated by the transmembrane Toll-like receptor TLR-4, which is a member of the larger family of Toll-like receptors involved in innate immunity (Beutler and Poltorak, 2000). Bovine mammary tissue expresses mRNA for TLR-4, as well as TLR-2, the latter of which is involved in host recognition of gram-positive bacteria (Goldammer et al., 2004). Although the exact mechanism by which LPS is recognized by TLR- 4 remains unclear, cell activation is dependent upon the cell surface assembly of a multiprotein recognition complex consisting of membrane-bound CD14 (mCD14), MD-2, and TLR-4 (Akashi et al., 2000). Endotoxin presentation to the aforementioned multiprotein complex is enhanced by the acute phase protein, LPS-binding protein (LBP; Tobias et al., 1999; Schumann and Latz, 2000). Lipopolysaccharide-binding protein and soluble CD14 (sCD14) are present in serum and facilitate the transfer of LPS to mCD14, a glycosylphosphatidylinositol-linked receptor on the surfaces of some host cells (Bannerman et al., 2003). It is thought that mCD14 subsequently interacts with TLR-4, the signaling component of the LPS receptor.

Cells lacking mCD14, including epithelial and endothelial cells, are capable of recognizing and responding to LPS. In the absence of mCD14, LBP facilitates the transfer of circulating LPS to sCD14, and this complex is recognized by TLR-4 (Tobias et al., 1999). Therefore, a common denominator to host cell recognition of LPS is the presence of CD14 as either a membrane-bound (mCD14) or soluble molecule (sCD14) and LBP.

Found on cells such as monocytes and macrophages, and to a lesser extent on neutrophils, mCD14 is a 55$\mathrm{kDa}$ glycoprotein (Viriyakosol et al., 2000). Soluble CD14 is derived from these cells by both direct exocytosis and proteolytic cleavage of cell surface mCD14. Although LPS binds CD14 directly, this process is greatly enhanced by LBP (Hailman et al., 1996). Lipo- polysaccharide-binding protein is a hepatocyte-derived acute phase protein, the expression of which is up-regulated by IL-1 and IL-6 (Tobias et al., 1999; Schumann and Latz, 2000). Lipopolysaccharide-binding protein is a lipid transfer molecule that dissociates LPS aggregates into monomers and catalyzes the transfer of these monomers to CD14. In addition, LBP has recently been shown to stabilize the association of LPS and CD14 by forming a tripartite complex (Thomas et al., 2002).

There is strong evidence for a protective role for CD14 and LBP in mediating the host response to gram-negative infections in the mammary gland of the cow (Bannerman et al., 2003; Lee et al., 2003; Vangroenweghe et al., 2004b). Detection of LPS is a critical event in activation of the innate response to gram-negative bacteria; however, an excess of LPS signaling can lead to exaggerated host responses, culminating in the development of septic shock.

\section{ENERGY METABOLISM AND NEUTROPHIL FUNCTION IN PERIPARTURIENT COWS}

Cows with low glucose, ketosis, fatty liver, and elevated NEFA are believed to have poorer immune function. A negative effect of ketone bodies on neutrophil function has been reported for both sheep and dairy cows (Hoeben et al., 1997, 2000; Sartorelli et al., 1999, 2000; Suriyasathaporn et al., 1999). The ketone bodies BHBA and acetoacetic acid inhibited the proliferation of hematopoietic cells at concentrations observed after parturition (Hoeben et al., 1999). A negative relation was found between PMN chemiluminescence and BHBA. Van Oostveldt et al. (2001) reported that apoptosis of PMN was higher in early-lactating than in mid-lactating cows. The severity of experimental $E$. coli mastitis in relation to in vitro chemotaxis of neutrophils was investigated in cows during negative energy balance induced by feed restriction. Cows were classified into 2 groups, ketonemic and nonketonemic, based on the BHBA concentration in the peripheral blood at the moment of inoculation. Bacterial growth in the inoculated quarter was used as a parameter to indicate the severity of experimental mastitis. In the nonketonemic cows, experimental mastitis ranged from moderate to severe. Severity of experimental mastitis was negatively related to the preinfection chemotactic response of neutrophils. In contrast, the course of experimental mastitis in the ketonemic group was relatively severe in all cows, regardless of the preinfection chemotactic response (Kremer et al., 1993).

In vitro studies of the effects of elevated NEFA levels on selected aspects of leukocyte activities have found DNA synthesis, IgM secretion, and secretion of IFN- $\gamma$ to be diminished at concentrations of NEFA often seen 
in the serum of periparturient dairy cows (Lacetera et al., 2004). In a recent study in which neutrophils were challenged with low to high NEFA concentrations, a biphasic effect was observed. Low NEFA concentrations decreased the oxidative burst after phagocytosis of Staph. aureus in comparison with controls (shamtreated), whereas high fatty acid concentrations primed the cells for an enhanced oxidative burst. This caused oxidative stress and subsequent necrosis. Phagocytosis activity was not affected by the tested concentrations of NEFA (Scalia et al., 2006). The authors concluded that increases of plasma NEFA might contribute to periparturient immunosuppression and the higher incidence of postpartum infections observed in cows with a negative energy balance. Palmitate stimulated free radical production in vitro through protein kinase $\mathrm{C}$ dependent activation of $\mathrm{NAD}(\mathrm{P}) \mathrm{H}$ oxidase in cultured human aortic smooth muscle cells and endothelial cells (Inoguchi et al., 2000).

\section{STEROID RECEPTOR EXPRESSION AND NEUTROPHIL FUNCTION IN PERIPARTURIENT COWS}

The mammary gland is subjected to major morphological and biochemical changes during the lactation cycle (Lamote et al., 2004b). The importance of the sex steroid hormones $17 \beta$-estradiol and progesterone for normal development of the mammary gland was recognized several decades ago and has been unequivocally confirmed since. It is now established that the influence of sex steroids is not restricted to mammogenesis, but that these hormones may also control immune function. Hormonal imbalances (Wetteman, 1980; Vangroenweghe et al., 2005) have been suggested to be implicated in the underlying mechanisms of the immunocompromised condition of the periparturient cow. An altered local inflammatory response, characterized by a chemotactic impairment of circulatory PMN, has been related to severe clinical mastitis. However, information on the interaction between sex steroid hormones and bovine PMN is scarce (Burvenich et al., 2003).

Historically, prepartum alterations in bovine PMN functions have been linked to high $17 \beta$-estradiol concentrations in blood plasma. In dairy cows, $17 \beta$-estradiol rises steeply during the last week of gestation and peaks during the last $3 \mathrm{~d}$ before parturition. At calving, $17 \beta$-estradiol falls rapidly to basal values. Progesterone, which is associated with pregnancy, declines suddenly at the end of gestation (i.e., during the last $2 \mathrm{~d}$ before calving; Bell, 1995; Moreira da Silva et al., 1998; Akers, 2002).

$17 \beta$-Estradiol has been suggested as one of the factors responsible for induction of a compromised PMN func- tion around parturition, which may alter the inflammatory reaction. The effect of $17 \beta$-estradiol and progesterone on diapedesis and viability of bovine neutrophils was studied in vitro with bovine mammary epithelial cells and fibroblasts. A decrease in the number of viable neutrophils was found after $17 \beta$-estradiol treatment, whereas no influence of progesterone was detected (Lamote et al., 2004a).

The effect of different concentrations of $17 \beta$-estradiol, estrone, or progesterone was also studied on isolated PMN from ovariectomized cows. No significant changes in PMN oxidative burst were observed at physiological or pharmacological levels of the 3 sex steroid hormones. A large variation existed in the oxidative burst activity among ovariectomized cows.

Mastectomy eliminated almost all the changes in leukocyte subset populations seen in intact cows around the time of parturition. It was concluded that the act of parturition, despite its attendant changes in plasma estrogens and cortisol, was not the main factor responsible for the immune cell population changes observed in the intact cows. Presumably, the changes seen during the periparturient period are the result of the onset of lactation (Kimura et al., 2002).

The majority of biological effects of estrogens are mediated through 2 distinct receptors, estrogen receptor (ER)- $\alpha$, and ER- $\beta$ (Speirs et al., 2004). Immune cells have long been considered to be ER-negative and were even used as negative controls in ER assays (Brotherick et al., 1995). The demonstration of ER in immune cells remains scarce, especially for ER- $\beta$ and mainly at the mRNA level. However, mRNA data do not provide information on whether the gene is translated into a protein. Recently, estrogen receptors have been detected in bovine neutrophils at both the protein level with flow cytometry, and at the mRNA level by PCR (Lamote et al., 2006). The modulatory role of estradiol on ER protein expression in neutrophils of cows was studied during the transition period. No difference was found for ER protein expression from cows in early lactation compared with late lactation. Endogenous $17 \beta$-estradiol and progesterone levels were not correlated with protein expression (Lamote et al., 2006).

Today, it is still unclear to what extent estrogenregulated genes in bovine neutrophils are involved in both pro- and anti-inflammatory responses to IMI in the periparturient cow. However, since ER- $\beta$ has now been detected on bovine PMN (Lamote et al., 2006), studies on the effect of estrogens on the PMN proteome with and without glucocorticoids would be a promising area for further research. Relative protein expression has been measured in neutrophils isolated during immunosuppression at parturition and compared with that from cows treated with an immunosuppressive 
dose of dexamethasone. Over 70 proteins were differentially expressed during dexamethasone treatment. The data demonstrated that there were both similarities and differences in neutrophil protein expression in the naturally occurring immunosuppression observed at parturition compared with dexamethasone-induced immunosuppression in the bovine neutrophil (Lippolis et al., 2006a).

Van Merris et al. (2004) investigated the effects of progesterone, $17 \beta$-estradiol, and hydrocortisone on 7-d proliferation of bovine progenitor cells in vitro. At low concentrations, $17 \beta$-estradiol inhibited proliferation of granulocyte progenitor cells. Hydrocortisone reduced growth of granulocyte and monocyte colonies, whereas myelopoiesis was not altered by progesterone. This study indicated that steroid hormones may be responsible for alterations in the bovine hematopoietic profiles observed in circulation during the postpartum period. Roets et al. (1999) observed that cortisol can induce a decrease in the expression of CD18 receptors after experimental $E$. coli infection in the lactating cow, thereby modulating the mammary inflammatory response. Reduced glucocorticoid receptor expression in blood PMN in periparturient dairy cows was associated with increased serum cortisol, leucocytosis, and neutrophilia. Glucocorticoid receptor down-regulation in neutrophils may be involved in periparturient neutrophil dysregulation and may cause an increased susceptibility to clinical mastitis (Weber et al., 2004).

\section{SOMATOTROPIN, IGF, AND BOVINE IMMUNE CONDITION}

Escherichia coli-induced mastitis promotes both apoptosis and cell proliferation. The number of apoptotic cells was significantly higher in mastitic than in uninfected control tissue. Expression of Bax- and IL$1 \beta$-converting enzyme increased in mastitic tissues, whereas Bcl-2 expression did not differ significantly from the control. Induction of matrix metalloproteinase-9, stromelysin-1, and urokinase-type plasminogen activator was also observed in the mastitic tissue. Moreover, cell proliferation increased in the infected tissue (Long et al., 2001).

Somatotropin is released during experimentally induced $E$. coli mastitis in periparturient cows (Burvenich et al., 1988, 1999; Shuster et al., 1995). The concentration of IGF-I in plasma did not change, whereas milk IGF-I increased significantly. Concentrations of IGF-I in milk whey increased from 5.0 to $12.2 \mathrm{ng} / \mathrm{mL}$ among infected glands and from 4.4 to $8.5 \mathrm{ng} / \mathrm{mL}$ among contralateral, uninfected glands. Insulin-like growth factor binding proteins also increased in the milk of infected glands (Shuster et al., 1995). This increase is probably due to leakage of plasma IGF-I into the mammary gland and to de novo synthesis in mammary epithelial cells. The local production of IGF by the mammary gland might be considered as a homeostatic mechanism that would overcome extensive apoptosis.

Cows were treated with recombinant bST (rbST) before (preinfection supplementation) and after (postinfection supplementation) experimentally induced $E$. coli mastitis (Vandeputte-Van Messom and Burvenich, 1993). The severity of disease was decreased and rbST had beneficial effects on minimizing milk production losses and compositional changes following IMI. Beneficial effects may have been mediated by the effect of IGF-I and rbST on neutrophil function. In vitro incubation of bovine PMN with rbST or IGF-I had no effect on the respiratory burst capacity of these cells. In contrast, treatment of healthy cows with rbST for $10 \mathrm{~d}$ stimulated neutrophil ROS production after 5 to $8 \mathrm{~d}$ of treatment (Burvenich et al., 1999), and also protected cows from excessive milk production losses and excessive milk compositional changes during clinical mastitis. Although not complete, the recovery of milk production and composition was markedly improved by preinfection and postinfection supplementation with rbST. Indeed, effects of IGF-I or somatotropin on the cytoskeleton, tubulin mRNA, and cytoskeletal reorganization have been reported in rats (Berfield et al., 1997; Goh et al., 1997).

\section{SELECTED APPROACHES TO IMPROVE THE RESISTANCE OF DAIRY COWS TO COLIFORM MASTITIS}

Many mastitis research groups are searching for ways to enhance resistance of the udder by enabling the mammary epithelium to secrete immune or antibacterial self and nonself (foreign) proteins. Proof of concept has already been obtained with transgenic mice and cows (Wall et al., 2005). Interest is focused on, for example, lysostaphin (a prokaryotic protein that has potent antistaphylococcal activity), lysozyme, lactoferrin, and sCD14. Inserting the gene for CD14 into the mammary gland will provide the CD14 necessary for recruitment of neutrophils and elimination of invading coliform mastitis-causing pathogens. Lysostaphin and human lysozyme are ineffective against $E$. coli and Streptococcus uberis isolates obtained from mastitis milk. Bovine $\beta$-defensin-related peptide has been expressed in the lactating mammary gland of transgenic mice (Yarus et al., 1996).

Transgenic application of immune or antibacterial proteins has at least 2 potential benefits: 1) unveiling candidate genes whose promoter elements enable temporal expression, and thus inducible expression of con- 
structs (e.g., delivering antibacterial proteins only when needed), the latter of which may be preferable to sustained constitutive expression, and 2) the sparing in agricultural use of antibiotics currently used in human medicine.

The importance of the neutrophil in protecting virtually all body tissues has been repeatedly demonstrated experimentally and in nature (Schalm et al., 1964a,b; Jain et al., 1968, 1978; Ackermann et al., 1993, 1996; Gilbert et al., 1993). Early and rapid accumulation of sufficient numbers of neutrophils is paramount in the ability of the host to effect a cure of invading pathogens (Anderson, 1983). The major role of neutrophils in the defense of the bovine mammary gland has been well documented (Schalm et al., 1964a,b, 1966; Jain et al., 1968). Effective methods of enhancing resistance of the bovine mammary gland by increasing the number of neutrophils in the mammary gland has been extensively tested but have been found to have limitations associated with tissue damage (Paape et al., 1981, 1988, 2002; Poutrel et al., 1983; Corlett et al., 1984; Paape and Corlett, 1984; Bright et al., 1987; Paape and Weinland, 1988; Peters et al., 1992). Another and perhaps more natural method to enhance disease resistance of immunosuppressed transition cows has been the use of cytokines that act to increase the number of circulating neutrophils. One of these cytokines, granulocyte-colony stimulating factor (G-CSF), has proved to be quite safe to administer (Cullor et al., 1990a,b) and will reduce the incidence of clinical coliform mastitis by $50 \%$ during the first week of lactation following experimental challenge (Kehrli, 1998). It has also been shown to be efficacious against Staph. aureus and Klebsiella pneumoniae in acute mastitis models (Nickerson et al., 1989; Kehrli et al., 1991). It is essential to understand that immunomodulators often work best in immunocompromised hosts; hence, the periparturient period is an excellent time for such compounds to be given to animals. Critical to the successful application of immumodulators is that they should not have adverse side effects. Granulocytecolony stimulating factor had no adverse effects on treated cows. The human equivalent of G-CSF has been successfully used for several years as an adjunct therapy for cancer patients undergoing chemotherapy.

In another study, the efficacy of 2 recombinant cytokines was evaluated, recombinant human G-CSF (rHuG-CSF) alone or in combination with recombinant bovine G-CSF (rBoGM-CSF), to enhance neutrophil function and prevent clinical mastitis following intramammary challenge with $E$. coli in dairy cows during the first week of lactation (Kehrli, 1997). Subcutaneous administration of rHuG-CSF alone or in combination with rBoGM-CSF was associated with induction of a significant increase in circulating neutrophils, although the combined treatment had a paradoxically lower increase in circulating neutrophils compared with $\mathrm{rHuG}$ CSF alone. The functional activity of circulating neutrophils was increased following cytokine treatment, as evidenced by priming of neutrophil myeloperoxidase activity. Animals treated with $\mathrm{rHuG-CSF}$ alone exhibited significantly improved clinical responses to challenge relative to the saline controls, including a $50 \%$ reduction in the number of new infections, faster bacterial clearance rates, and reduced clinical severity scores. Mastitis resulted in decreased milk production and feed consumption. Animals treated with $\mathrm{rHuG}-\mathrm{CSF}$ exhibited significantly improved milk production and feed consumption relative to saline controls. Milk composition analysis indicated that cows treated with rHuG-CSF alone or in combination with rBoGM-CSF exhibited improved lactose levels relative to controls. In conclusion, G-CSF provided significant protection against coliform mastitis in dairy cows $6 \mathrm{~d}$ after calving.

\section{CONCLUSION AND PERSPECTIVES}

The most clinically evident effect of periparturient stressors on dairy cows may be immunosuppression, thus explaining the high incidence of opportunistic infections such as clinical coliform mastitis. Periparturient immunosuppression is unlikely to be the result of a single physiological factor; more likely, several entities will be found to act in concert, with profound effects on the function of many organ systems of the periparturient dairy cow. The easiest prophylaxis today to prevent periparturient toxic mastitis is to provide periparturient cows not only with optimal hygiene conditions, but also with appropriate diets during the transition period and as few additional stress events as possible around calving. The metabolic demands of increasing milk secretion (protein and energy) affect the ability of the periparturient cow to manage its metabolism, as well as its ability to recover from an immunocompromised condition. Many theories exist on how better to manage the metabolic changes in the transition cow. Central to all these theories is to maximize feed intake and minimize serum NEFA levels around calving to maximize the profitability of the transition cow.

Based on culmulative research identifying different factors that contribute to periparturient immunosuppression, the development of novel interventions that modulate the inflammatory response or enhance effector cell function or both may offer some promise for preventing or treating IMI in periparturient cows. Two main approaches can be used to modulate the innate resistance of the udder. The first is to enhance the efficacy of the efferent arm of innate immunity, that is, modulation of the attraction of competent phagocytes. 
It is generally accepted that the ability of neutrophils to ingest and kill bacteria is pivotal for the control of IMI. The second is to enhance fast detection of pathogens in the teat and udder cistern (afferent arm of innate immunity). Recognition of microbial molecular patterns by Toll-like receptors and other signaling pathways contribute to fast recognition. These receptors enhance expression of cytokines, in turn amplifying host responses to the pathogen. Such therapies must be achieved without causing exuberant inflammation that ultimately injures the mammary gland and increases mortality of the host. At the moment, many mastitis research groups are searching to enhance resistance of the udder by enabling the mammary epithelium to secrete immune or antibacterial self and nonself (foreign) proteins. For example, proof of concept has been obtained with transgenic mice and cows (Wall et al., 2005). Interest is focused on, for example, lysostaphin (a prokaryotic protein that has potent antistaphylococcal activity), lysozyme, lactoferrin, and soluble CD14. Inserting the gene for CD14 into the mammary gland will provide the CD14 necessary for recruitment of neutrophils and elimination of invading coliform mastitis-causing pathogens. Transgenic application of immune or antibacterial proteins is expected to unveil candidate genes whose promoter elements will enable temporal expression patterns. These genes could eventually be expressed through administration as food additives (certain fatty acids, for example, are known to be very active at the level of gene expression). Theoretically, inflammation-inducible expression constructs are superior to constitutive espression because the antibacterial proteins are only provided when needed.

\section{REFERENCES}

Ackermann, M. R., M. E. Kehrli Jr., J. A. Laufer, and L. T. Nusz. 1996. Alimentary and respiratory tract lesions in eight medically fragile Holstein cattle with bovine leukocyte adhesion deficiency (BLAD). Vet. Pathol. 33:273-281.

Ackermann, M. R., M. E. Kehrli Jr., and D. C. Morfitt. 1993. Ventral dermatitis and vasculitis in calf with bovine leukocyte adhesion deficiency. J. Am. Vet. Med. Assoc. 202:413-415.

Akashi, S., H. Ogata, F. Kirikae, T. Kirikae, K. Kawasaki, M. Nishijima, R. Shimazu, Y. Nagai, K. Fukudome, M. Kimoto, and K. Miyake. 2000. Regulatory roles for CD14 and phosphatidylinositol in the signaling via Toll-like receptor 4-MD-2. Biochem. Biophys. Res. Commun. 5:172-177.

Akers, M. 2002. Lactation and the Mammary Gland. Iowa State Press, Ames.

Ametaj, B. N., D. C. Beitz, T. A. Reinhardt, and B. J. Nonnecke. 1996. 1,25-Dihydroxyvitamin $\mathrm{D}_{3}$ inhibits secretion of interferon- $\gamma$ by mitogen- and antigen-stimulated bovine mononuclear leukocytes. Vet. Immunol. Immunopathol. 52:77-90.

Ametaj, B. N., B. J. Nonnecke, R. L. Horst, and D. C. Beitz. 2000. Effects of retinoic acid and 1,25-dihydroxyvitamin $\mathrm{D}_{3}$ on IFN- $\gamma$ secretion by mononuclear leukocytes from nulliparous and postparturient dairy cattle. Int. J. Vitam. Nutr. Res. 70:92-101.

Anderson, J. C. 1983. The mouse mastitis model: Observations relevant to the treatment and control of coliform mastitis. Vet. Res. Commun. 7:223-227.
Anderson, K. L., A. R. Smith, B. K. Gustaffson, S. L. Spahr, and H. L. Whitmore. 1982. Diagnosis and treatment of acute mastitis in a large dairy herd. J. Am. Vet. Med. Assoc. 181:690-693.

Anri, A. 1989. Detection of endotoxin in affected milk from cows with coliform mastitis. Nippon Juigaku Zasshi 51:847-848.

Bannerman, D. D., M. J. Paape, W. R. Hare, and E. J. Sohn. 2003. Increased levels of LPS-binding protein in bovine blood and milk following bacterial lipopolysaccharide challenge. J. Dairy Sci. 86:3128-3137.

Bell, A. 1995. Regulation of organic nutrient metabolism during transition from late pregnancy to early lactation. J. Anim. Sci. 73:2804-2819.

Berfield, A. K., D. Spicer, and C. K. Abrass. 1997. Insulin-like growth factor I (IGF-I) induces unique effects in the cytoskeleton of cultured rat glomerular mesangial cells. J. Histochem. Cytochem. 45:583-593.

Beutler, B. 2004. Innate immunity: An overview. Mol. Immunol. 40:845-859.

Beutler, B., and A. Poltorak. 2000. Positional cloning of LPS, and the general role of Toll-like receptors in the innate immune response. Eur. Cytokine Netw. 11:143-152.

Blum, J. W., H. Dosogne, D. Hoeben, F. Vangroenweghe, H. M. Hammon, R. M. Bruckmaier, and C. Burvenich. 2000. Tumor necrosis factor- $\alpha$ and nitrite/nitrate responses during acute mastitis induced by Escherichia coli infection and endotoxin in dairy cows. Domest. Anim. Endocrinol. 19:223-235.

Boulanger, D., F. Bureau, D. Melotte, J. Mainil, and P. Lekeux. 2003. Increased nuclear factor kappaB activity in milk cells of mastitisaffected cows. J. Dairy Sci. 86:1259-1267.

Bright, S. A., W. D. Schultze, M. J. Paape, and R. R. Peters. 1987. Effect of intramammary devices on the outcome of induced Escherichia coli infection of bovine mammary quarters. Am. J. Vet. Res. 48:1290-1294.

Brinkmann, V., U. Reichard, C. Goosmann, B. Fauler, Y. Uhlemann, D. S. Weiss, Y. Weinrauch, and A. Zychlinsky. 2004. Neutrophil extracellular traps kill bacteria. Science 303:1532-1535.

Brotherick, I., T. Lennard, S. Cook, R. Johnstone, B. Angus, M. Winterheik, and B. Shenton. 1995. Use of the biotinylated antibody DAKO-ER 1D5 to measure oestrogen receptor on cytokeratin positive cells obtained from primary breast cancer cells. Cytometry 20:74-80.

Burton, J. L., and M. E. Kehrli Jr. 1995. Regulation of neutrophil adhesion molecules and shedding of Staphylococcus aureus in milk of cortisol- and dexamethasone-treated cows. Am. J. Vet. Res. 56:997-1006.

Burton, J. L., M. E. Kehrli Jr., S. Kapil, and R. L. Horst. 1995. Regulation of L-selectin and CD18 on bovine neutrophils by glucocorticoids: Effects of cortisol and dexamethasone. J. Leukoc. Biol. $57: 317-325$.

Burvenich, C., J. Detilleux, M. J. Paape, and A. M. Massart-Leën. 2000. Physiolocial and genetic factors that influence the cows resistance to mastitis, especially during early lactation. Pages 920 in Proc. Int. Dairy Fed. Symp. Immunol. Rumin. Mammary Gland. A. Zecconi, ed. Stresa, Italy.

Burvenich, C., E. Monfardini, J. Mehrzad, A. V. Capuco, and M. J. Paape. 2004. Role of neutrophil polymorphonuclear leukocytes during bovine coliform mastitis: Physiology or pathology? Verh. K. Acad. Geneeskd. Belg. 66:97-153.

Burvenich, C., M. J. Paape, A. W. Hill, A. J. Guidry, R. H. Miller, R. Heyneman, W. D. J. Kremer, and A. Brand. 1994. Role of the neutrophil leukocyte in the local and systemic reactions during experimentally induced $E$. coli mastitis in cows immediately after calving. Vet. Q. 16:45-50.

Burvenich, C., M. J. Paape, D. Hoeben, H. Dosogne, A. M. MassartLeën, and J. Blum. 1999. Modulation of the inflammatory reaction and neutrophil defense of the bovine lactating mammary gland by growth hormone. Domest. Anim. Endocrinol. 17:149-159.

Burvenich, C., G. Vandeputte-Van Messom, E. Roets, A. M. MassartLeën, R. M. Akers, R. Reynaert-Van Sichem, and L. Devrieze. 1988. Bovine growth hormone on acute mastitis due to Escherichia coli. Ann. Med. Vet. 132:601-606. 
Burvenich, C., V. Van Merris, J. Mehrzad, A. Diez-Fraile, and L. Duchateau. 2003. Severity of E. coli mastitis is mainly determined by cow factors. Vet. Res. 34:521-564.

Cai, T.-Q., P. G. Weston, L. A. Lund, B. Brodie, D. J. McKenna, and W. C. Wagner. 1994. Association between neutrophil functions and periparturient disorders in cows. Am. J. Vet. Res. 55:934-943.

Carroll, E. J., O. W. Schalm, and J. Lasmanis. 1964. Experimental coliform (Aerobacter aerogenes) mastitis: Characteristics of the endotoxin and its role in pathogenesis. Am. J. Vet. Res. 25:720-726.

Cooray, R. 1996. Casein effects on the myeloperoxidase-mediated oxygen-dependent bactericidal activity of bovine neutrophils. Vet. Immunol. Immunopathol. 51:55-65.

Corlett, N. J., R. R. Peters, M. J. Paape, and W. D. Schultze. 1984. Effect of intramammary device on new infection rate, milk yield, and milk somatic cell counts in Maryland dairy herds. J. Dairy Sci. 67:2571-2579.

Cullor, J. S., N. Fairley, W. L. Smith, S. L. Wood, J. D. Dellinger, M. Inokuma, and L. M. Souza. 1990a. Hemogram changes in lactating dairy cows given human recombinant granulocyte colony-stimulating factor (r-MethuG-CSF). Vet. Pathol. 27:311-316.

Cullor, J. S., W. Smith, N. Fairley, S. L. Wood, J. D. Dellinger, and L. Souza. 1990b. Effects of human recombinant granulocyte colony stimulating factor (HR-GCSF) on the hemogram of lactating dairy cattle. Vet. Clin. Pathol. 19:9-12.

Daynes, R. A., E. Y. Enioutina, S. Butler, H.-H. Mu, Z. A. McGee, and B. A. Araneo. 1996. Induction of common mucosal immunity by hormonally immunomodulated peripheral immunization. Infect. Immun. 64:1100-1109.

Detilleux, J. C. 2002. Genetic factors affecting susceptibility of dairy cows to udder pathogens. Vet. Immunol. Immunopathol. 88:103-110.

Detilleux, J. C., M. E. Kehrli Jr., J. R. Stabel, A. E. Freeman, and D. H. Kelley. 1995. Study of immunological dysfunction in periparturient Holstein cattle selected for high and average milk production. Vet. Immunol. Immunopathol. 44:251-267.

Detilleux, J. C., K. J. Koehler, A. E. Freeman, M. E. Kehrli Jr., and D. H. Kelley. 1994. Immunological parameters of periparturient Holstein cattle: Genetic variation. J. Dairy Sci. 77:2640-2650.

Detilleux, J., F. Vangroenweghe, and C. Burvenich. 2006. Mathematical model of the acute inflammatory response to Escherichia coli in intramammary challenge. J. Dairy Sci. 89:3455-3465.

Dhondt, G., C. Burvenich, and G. Peeters. 1977. Mammary blood flow during experimental Escherichia coli endotoxin induced mastitis in goats and cows. J. Dairy Res. 44:433-440.

Diez-Fraile, A., E. Meyer, and C. Burvenich. 2002. Regulation of adhesion molecules on circulating neutrophils during coliform mastitis and their possible immunomodulation with drugs. Vet. Immunol. Immunopathol. 86:1-10.

Diez-Fraile, A., E. Meyer, and C. Burvenich. 2003. Sympathoadrenal and immune system activation during the periparturient period and their association with bovine coliform mastitis. Vet. Q. 25:3144. (erratum in Vet. Q. 25:79)

Dosogne, H., C. Burvenich, A. E. Freeman, M. E. Kehrli Jr., J. C. Detilleux, J. Sulon, J.-F. Beckers, and D. Hoeben. 1999. Association between pregnancy-associated glycoprotein and decreased polymorphonuclear leukocyte function in early postpartum dairy cows. Vet. Immunol. Immunopathol. 67:47-54.

Dosogne, H., A. V. Capuco, M. J. Paape, E. Roets, C. Burvenich, and B. Fenwick. 1998. Reduction of acyloxyacyl hydrolase activity in circulating neutrophils from cows after parturition. J. Dairy Sci. 81:672-677.

Dosogne, H., E. Meyer, A. Sturk, J. van Loon, A. M. Massart-Leën, and C. Burvenich. 2002. Effect of enrofloxacin treatment on plasma endotoxin during bovine Escherichia coli mastitis. Inflamm. Res. 51:201-205.

Erskine, R. J., J. W. Tyler, M. G. Riddell Jr., and R. C. Wilson. 1991. Theory, use, and realities of efficacy and food safety of antimicrobial treatment of acute coliform mastitis. J. Am. Vet. Med. Assoc. 198:980-984.
Gilbert, R. O., Y. T. Grohn, C. L. Guard, V. Surman, N. Neilsen, and D. O. Slauson. 1993. Impaired post partum neutrophil function in cows which retain fetal membranes. Res. Vet. Sci. 55:15-19.

Goh, E. L., T. J. Pircher, T. J. Wood, G. Norstedt, R. Graichen, and P. E. Lobie. 1997. Growth hormone-induced reorganization of the actin cytoskeleton is not required for STAT5 (signal transducer and activator of transcription-5)-mediated transcription. Endocrinology 138:3207-3215.

Goldammer, T., H. Zerbe, A. Molenaar, H. J. Schuberth, R. M. Brunner, S. R. Kata, and H. M. Seyfert. 2004. Mastitis increases mammary mRNA abundance of beta-defensin 5, Toll-like-receptor 2 (TLR2), and TLR4 but not TLR9 in cattle. Clin. Diagn. Lab. Immunol. 11:174-185.

Gonzalez, R. N., J. S. Cullor, D. E. Jasper, T. B. Farver, R. B. Bushnell, and M. N. Oliver. 1989. Prevention of clinical coliform mastitis in dairy cows by a mutant Escherichia coli vaccine. Can. J. Vet. Res. 53:301-305.

Grün, E. 1985. The physiological and diagnostic importance of lysozyme in cow's milk. Allerg. Immunol. (Leipzig) 31:3-15.

Hailman, E., T. Vasselon, M. Kelley, L. A. Busse, M. C. Hu, H. S. Lichenstein, P. A. Detmers, and S. D. Wright. 1996. Stimulation of macrophages and neutrophils by complexes of lipopolysaccharide and soluble CD14. J. Immunol. 156:4384-4390.

Heyneman, R., C. Burvenich, and R. Vercauteren. 1990. Interaction between the respiratory burst activity of neutrophil leukocytes and experimentally induced Escherichia coli mastitis in cows. J. Dairy Sci. 73:985-994.

Hill, A. W. 1981. Factors influencing the outcome of Escherichia coli mastitis in the dairy cow. Res. Vet. Sci. 31:107-112.

Hill, A. W., A. L. Shears, and K. G. Hibbitt. 1979. The pathogenesis of experimental Escherichia coli mastitis in newly calved dairy cows. Res. Vet. Sci. 26:97-101.

Hirsch, J. G. 1958. Bactericidal action of histone. J. Exp. Med. 108:925-944.

Hirvonen, J., K. Eklund, A. M. Teppo, G. Huszenicza, M. Kulcsar, H. Saloniemi, and S. Pyorala. 1999. Acute phase response in dairy cows with experimentally induced Escherichia coli mastitis. Acta Vet. Scand. 40:35-46.

Hoeben, D., C. Burvenich, A. M. Massart-Leën, M. Lenjou, G. Nijs, D. Van Bockstaele, and J. F. Beckers. 1999. In vitro effect of ketone bodies, glucocorticosteroids and bovine pregnancy-associated glycoprotein on cultures of bone marrow progenitor cells of cows and calves. Vet. Immunol. Immunopathol. 68:229-240.

Hoeben, D., R. Heyneman, and C. Burvenich. 1997. Elevated levels of beta-hydroxybutyric acid in periparturient cows and in vitro effect on respiratory burst activity of bovine neutrophils. Vet. Immunol. Immunopathol. 58:165-170.

Hoeben, D., E. Monfardini, G. Opsomer, C. Burvenich, H. Dosogne, A. de Kruif, and J. F. Beckers. 2000. Chemiluminescence of bovine polymorphonuclear leucocytes during the periparturient period and relation with metabolic markers and bovine pregnancy-associated glycoprotein. J. Dairy Res. 67:249-259.

Hogan, J. S., K. L. Smith, K. H. Hoblet, P. S. Schoenberger, D. A Todhunter, W. D. Hueston, D. E. Pritchard, G. L. Bowman, L. E. Heider, B. L. Brockett, and H. R. Conard. 1989. Field survey of clinical mastitis in low somatic cell count herds. J. Dairy Sci. 72:1547-1556.

Hogan, J. S., W. P. Weiss, D. A. Todhunter, K. L. Smith, and P. S. Schoenberger. 1992. Efficacy of an Escherichia coli J5 mastitis vaccine in an experimental challenge trial. J. Dairy Sci. 75:415-422.

Inoguchi, T., P. Li, F. Umeda, H. Y. Yu, M. Kakimoto, M. Imamura, T. Aoki, T. Etoh, T. Hashimoto, M. Naruse, H. Sano, H. Utsumi, and H. Nawata. 2000. High glucose level and free fatty acid stimulate ROS production through protein kinase C-dependent activation of $\mathrm{NAD}(\mathrm{P}) \mathrm{H}$ oxidase in cultured vascular cells. Diabetes 49:1939-1945

Ishikawa, H., T. Shirahata, and K. Hasegawa. 1994. Interferon- $\gamma$ production of mitogen stimulated peripheral lymphocytes in perinatal cows. J. Vet. Med. Sci. 56:735-738.

Jain, N. C., O. W. Schalm, E. J. Carroll, and J. Lasmanis. 1968 Experimental mastitis in leukopenic cows: Immunologically in- 
duced neutropenia and response to intramammary inoculation of Aerobacter aerogenes. Am. J. Vet. Res. 29:2089-2097.

Jain, N. C., O. W. Schalm, and J. Lasmanis. 1971. Experimentally induced coliform (Aerobacter aerogenes) mastitis in normal cows and in cows made neutropenic by an equine anti-bovine leukocyte serum. Am. J. Vet. Res. 32:1929-1935.

Jain, N. C., O. W. Schalm, and J. Lasmanis. 1978. Neutrophil kinetics in endotoxin-induced mastitis. Am. J. Vet. Res. 39:1662-1667.

Jones, G. F., and G. E. Ward. 1990. Evaluation of systemic administration of gentamicin for treatment of coliform mastitis in cows. J. Am. Vet. Med. Assoc. 197:731-735.

Katholm, J., and P. H. Andersen. 1992. Acute coliform mastitis in dairy cows: Endotoxin and biochemical changes in plasma and colony-forming units in milk. Vet. Rec. 131:513-514.

Keane, C. J., A. J. Hanlon, J. F. Roche, J. L. Burton, J. F. Mee, J. V. O'Doherty, and T. Sweeney. 2006. Short communication: A potential antiapoptotic phenotype in neutrophils of cows milked once daily in early lactation. J. Dairy Sci. 89:1024-1027.

Kehrli, M. E., Jr. 1997. Efficacy of granulocyte-colony stimulatory factor alone or in combination with granulocyte macrophage-CSF against Escherichia coli bovine mastitis. Page 88 in 78th Conf. Res. Workers Anim. Disease, Chicago, IL. R. P. Ellis, ed. Blackwell Publishing, Ames, IA.

Kehrli, M. E., Jr. 1998. Efficacy of granulocyte-colony stimulatory factor as an immunomodulator to prevent Escherichia coli mastitis during early lactation. Pages 336-338 in 37th Ann. Mtg. Nat. Mastitis Counc., St. Louis, MO. National Mastitis Council, Madison, WI.

Kehrli, M. E., Jr., and J. P. Goff. 1989. Periparturient hypocalcemia in cows: Effects on peripheral blood neutrophil and lymphocyte function. J. Dairy Sci. 72:1188-1196.

Kehrli, M. E., Jr., J. Cullor, and S. C. Nickerson. 1991. Immunobiology of hematopoietic colony-stimulatory factors: Potential application to disease prevention in the bovine. J. Dairy Sci. 74:4399-4412.

Kehrli, M. E., Jr., B. J. Nonnecke, and J. A. Roth. 1989a. Alterations in bovine lymphocyte function during the periparturient period. Am. J. Vet. Res. 50:215-220.

Kehrli, M. E., Jr., B. J. Nonnecke, and J. A. Roth. 1989b. Alterations in bovine neutrophil function during the periparturient period. Am. J. Vet. Res. 50:207-214.

Kehrli, M. E., Jr., and S. M. Sakya. 2003. Methods of treating acute inflammation in animals with P38 MAP kinase inhibitors. US Patent Appl. S.N. 11/014392, December 16, 2004.

Kehrli, M. E., Jr., D. E. Shuster, J. R. Stabel, M. G. Stevens, J. R. Thurston, and M. Daley. 1997. Effects of recombinant bovine granulocyte-macrophage-colony stimulatory factor administration on the bovine immune system and resistance to intramammary challenge with Escherichia coli. In Virtual Conference on Infectious Diseases of Animals. National Animal Disease CenterUSDA-ARS, Ames, IA. Available: http://www.nadc.ars.usda.gov/ virtconf/subpost/posters/G00044.htm Accessed Feb. 22, 2007.

Kimura, K., J. P. Goff, and M. E. Kehrli Jr. 1999a. Effects of the presence of the mammary gland on expression of neutrophil adhesion molecules and myeloperoxidase activity in periparturient dairy cows. J. Dairy Sci. 82:2385-2392.

Kimura, K., J. P. Goff, M. E. Kehrli Jr., and J. A. Harp. 1999b. Phenotype analysis of peripheral blood mononuclear cells in periparturient dairy cows. J. Dairy Sci. 82:315-319.

Kimura, K., J. P. Goff, M. E. Kehrli Jr., J. A. Harp, and B. J. Nonnecke. 2002. Effects of mastectomy on composition of peripheral blood mononuclear cell populations in periparturient dairy cows. J. Dairy Sci. 85:1437-1444.

Kindzelskii, A. L., T. Ueki, H. Michibata, T. Chaiworapongsa, R. Romero, and H. R. Petty. 2004. 6-Phosphogluconate dehydrogenase and glucose-6-phosphate dehydrogenase form a supramolecular complex in human neutrophils that undergoes retrograde trafficking during pregnancy. J. Immunol. 172:6373-6381.

Kirk, J. H., and P. C. Barlett. 1984. Nonclinical Pseudomonas aeruginosa mastitis in a dairy herd. J. Am. Vet. Med. Assoc. 184:671-673.

Kremer, W. D., E. N. Noordhuizen-Stassen, F. J. Grommers, Y. H. Schukken, R. Heeringa, A. Brand, and C. Burvenich. 1993. Sever- ity of experimental Escherichia coli mastitis in ketonemic and nonketonemic dairy cows. J. Dairy Sci. 76:3428-3436.

Lacetera, N., D. Scalia, O. Franci, U. Bernabucci, B. Ronchi, and A. Nardone. 2004. Effects of nonesterified fatty acids on lymphocyte function in dairy heifers. J. Dairy Sci. 87:1012-1014.

Lamote, I., E. Meyer, A. De Ketelaere, L. Duchateau, and C. Burvenich. 2006. Expression of the estrogen receptor in blood neutrophils of dairy cows during the periparturient period. Theriogenology 65:1082-1098.

Lamote, I., E. Meyer, L. Duchateau, and C. Burvenich. 2004a. Influence of $17 \beta$-estradiol, progesterone, and dexamethasone on diapedesis and viability of bovine blood polymorphonuclear leukocytes. J. Dairy Sci. 87:3340-3349.

Lamote, I., E. Meyer, A. M. Massart-Leën, and C. Burvenich. 2004b. Sex steroids and growth factors in the regulation of mammary gland proliferation, differentiation, and involution. Steroids 69:145-159.

Lee, E.-K., and M. E. Kehrli Jr. 1998. Expression of adhesion molecules on neutrophils of periparturient cows and neonatal calves. Am. J. Vet. Res. 59:37-43.

Lee, J.-L., M. J. Paape, T. H. Elsasser, and A. Zhao. 2003. Recombinant soluble CD14 reduces severity of intramammary infection by Escherichia coli. Infect. Immun. 71:4034-4039.

Lippolis, J. D., B. D. Peterson-Burch, and T. A. Reinhardt. 2006a. Differential expression analysis of proteins from neutrophils in the periparturient period and neutrophils from dexamethasonetreated dairy cows. Vet. Immunol. Immunopathol. 111:149-164.

Lippolis, J. D., and T. A. Reinhardt. 2005. Proteomic survey of bovine neutrophils. Vet. Immunol. Immunopathol. 103:53-65.

Lippolis, J. D., T. A. Reinhardt, J. P. Goff, and R. L. Horst. 2006b. Neutrophil extracellular trap formation is not inhibited by milk. Vet. Immunol. Immunopathol. 113:248-255.

Lohuis, J. A., Y. H. Schukken, P. A. Henricks, R. Heyneman, C. Burvenich, J. H. Verheijden, A. S. Van Miert, and A. Brand. 1990. Preinfection functions of blood polymorphonuclear leukocytes and the outcome of experimental Escherichia coli mastitis in the cow. J. Dairy Sci. 73:342-350.

Long, E., A. V. Capuco, D. L. Wood, T. Sonstegard, G. Tomita, M. J. Paape, and X. Zhao. 2001. Escherichia coli induces apoptosis and proliferation of mammary cells. Cell Death Differ. 8:808-816.

Malinowski, E. 2002. The use of some immunomodulators and nonantibiotic drugs in a prophylaxis and treatment of mastitis. Pol. J. Vet. Sci. 5:197-202.

Malinowski, E., J. Krzyzanowski, W. Wawron, J. Slawomirski, and J. Gluszak. 1983. Analysis of cases of Escherichia coli mastitis in cows. Med. Weter. 39:608-610.

Massart-Leën, A. M., C. Burvenich, G. Vandeputte-Van Messom, and H. Hilderson. 1992. Partial prostaglandin-mediated mechanism controlling the release of cortisol in plasma after intravenous administration of endotoxins. Domest. Anim. Endocrinol. 9:273-283.

Mattila, T., and A. J. Frost. 1989. Induction by endotoxin of the inflammatory response in the lactating and dry bovine mammary gland. Res. Vet. Sci. 46:238-240.

McDermott, C. M., J. S. Cullor, and B. W. Fenwick. 1991a. Intracellular and extracellular enzymatic deacylation of bacterial endotoxin during localized inflammation induced by Escherichia coli. Infect. Immun. 59:478-485.

McDermott, C. M., J. L. Morrill, and B. W. Fenwick. 1991b. Deacylation of endotoxin during natural cases of bovine mastitis. J. Dairy Sci. 74:1227-1234.

McDonald, J. S., and A. J. Anderson. 1981. Total and differential somatic cell counts in secretions from noninfected bovine mammary glands: The peripartum period. Am. J. Vet. Res. 42:1360-1368.

Mehrzad, J., H. Dosogne, E. Meyer, and C. Burvenich. 2001a. Local and systemic effects of endotoxin mastitis on the chemiluminescence of milk and blood neutrophils in dairy cows. Vet. Res. 32:131-144.

Mehrzad, J., H. Dosogne, E. Meyer, R. Heyneman, and C. Burvenich. 2001b. Respiratory burst activity of blood and milk neutrophils 
in dairy cows during different stages of lactation. J. Dairy Res. 68:399-415.

Mehrzad, J., L. Duchateau, and C. Burvenich. 2004. Viability of milk neutrophils and severity of bovine coliform mastitis. J. Dairy Sci. 87:4150-4162.

Mehrzad, J., L. Duchateau, S. Pyorala, and C. Burvenich. 2002. Blood and milk neutrophil chemiluminescence and viability in primiparous and pluriparous dairy cows during late pregnancy, around parturition and early lactation. J. Dairy Sci. 85:3268-3276.

Monfardini, E., M. J. Paape, Y. Wang, A. V. Capuco, M. Husheem, L. Wood, and C. Burvenich. 2002. Evaluation of L-selectin expression and assessment of protein tyrosine phosphorylation in bovine polymorphonuclear neutrophil leukocytes around parturition. Vet. Res. 33:271-281.

Monfardini, E., V. Van Merris, M. J. Paape, L. Duchateau, and C. Burvenich. 2004. L-selectin and chemotaxis throughout bone marrow granulocyte maturation in the bovine. J. Dairy Sci. 87:3350-3357.

Moreira da Silva, F., C. Burvenich, A. M. Massart-Leën, and L. Brossé. 1998. Assessment of blood neutrophil oxidative burst activity in dairy cows during the period of parturition. Anim. Sci. 67:421-426.

Mwangi, S. M., J. Stabel, E. Lee, M. E. Kehrli, and M. J. Taylor. 2000. Expression and characterization of a recombinant soluble form of bovine tumor necrosis factor receptor type I. Vet. Immunol. Immunopathol. 77:233-241.

Nickerson, S. C. 1989. Immunological aspects of mammary involution. J. Dairy Sci. 72:1665-1678.

Nickerson, S. C., W. E. Owens, and J. L. Watts. 1989. Effects of recombinant granulocyte colony-stimulating factor on Staphylococcus aureus mastitis in lactating dairy cows. J. Dairy Sci. $72: 3286-3294$

Nonnecke, B. J., K. Kimura, J. P. Goff, and M. E. Kehrli Jr. 2003. Effects of the mammary gland on functional capacities of blood mononuclear leukocyte populations from periparturient cows. J. Dairy Sci. 86:2359-2368.

Oliver, S. P., and T. Bushe. 1987. Growth inhibition of Escherichia coli and Klebsiella pneumoniae during involution of the bovine mammary gland: Relation to secretion composition. Am. J. Vet. Res. 48:1669-1673.

Oliver, S. P., and L. M. Sordillo. 1988. Udder health in the periparturient period. J. Dairy Sci. 71:2584-2606.

Paape, M. J., D. D. Bannerman, X. Zhao, and J. W. Lee. 2003. The bovine neutrophil: Structure and function in blood and milk. Vet. Res. 34:597-627.

Paape, M. J., and N. J. Corlett. 1984. Intensification of milk somatic cell response to intramammary device. Am. J. Vet. Res. 45:1572-1575.

Paape, M. J., and A. J. Guidry. 1977. Effect of fat and casein on intracellular killing of Staphylococcus aureus by milk leukocytes. Proc. Soc. Exp. Biol. Med. 155:588-593.

Paape, M. J., A. J. Guidry, S. T. Kirk, and D. J. Bolt. 1975. Measurement of phagocytosis of ${ }^{32} \mathrm{P}$-labeled Staphylococcus aureus by bovine leukocytes: Lysostaphin digestion and inhibitory effect of cream. Am. J. Vet. Res. 36:1737-1743.

Paape, M. J., J. Mehrzad, X. Zhao, J. Detilleux, and C. Burvenich. 2002. Defense of the bovine mammary gland by polymorphonuclear neutrophil leukocytes. J. Mammary Gland Biol. Neoplasia $7: 109-121$.

Paape, M. J., W. D. Schultze, N. J. Cortlett, and B. T. Weinland. 1988. Effect of abraded intramammary device on outcome in lactating cows after challenge exposure with Streptococcus uberis. Am. J. Vet. Res. 49:790-792.

Paape, M. J., W. D. Schultze, C. Desjardins, and R. H. Miller. 1974. Plasma corticosteroid, circulating leukocyte and milk somatic cell responses to Escherichia coli endotoxin-induced mastitis. Proc. Soc. Exp. Biol. Med. 145:553-559.

Paape, M. J., W. D. Schultze, A. J. Guidry, W. M. Kortum, and B. T. Weinland. 1981. Effect of an intramammary polyethylene device on the concentration of leukocytes and immunoglobulins in milk and on the leukocyte response to Escherichia coli endotoxin and challenge exposure with Staphylococcus aureus. Am. J. Vet. Res. 42:774-783.

Paape, M. J., K. Shafer-Weaver, A. V. Capuco, K. Van Oostveldt, and C. Burvenich. 2000. Immune surveillance of mammary tissue by phagocytic cells. Adv. Exp. Med. Biol. 480:259-277.

Paape, M. J., and B. T. Weinland. 1988. Effect of abraded intramammary device on milk yield, tissue damage, and cellular composition. J. Dairy Sci. 71:250-256.

Peters, R. R., R. A. Le Dane, L. W. Douglass, and M. J. Paape. 1992. Intramammary response to modified intramammary devices. J. Dairy Sci. 75:85-95.

Poutrel, B., M. J. Paape, C. Lerondelle, and R. Grappin. 1983. Attempts at preventing experimental Staphylococcus aureus mastitis by immunization and intramammary insertion of a polyethylene device. Ann. Rech. Vet. 14:13-20.

Rainard, P. 1986a. Bacteriostatic activity of bovine milk lactoferrin against mastitic bacteria. Vet. Microbiol. 11:387-392.

Rainard, P. 1986b. Bacteriostasis of Escherichia coli by bovine lactoferrin, transferrin and immunoglobulins (IgG1, IgG2, IgM) acting alone or in combination. Vet. Microbiol. 11:103-115.

Rainard, P., and C. Riollet. 2006. Innate immunity of the bovine mammary gland. Vet. Res. 37:369-400

Rejman, J. J., H. M. Hegarty, and W. L. Hurley. 1989. Purification and characterization of bovine lactoferrin from secretions of the involuting mammary gland: Identification of multiple molecular weight forms. Comp. Biochem. Physiol. B 93:929-934.

Roets, E., C. Burvenich, A. Diez-Fraile, and E. N. Noordhuizen-Stassen. 1999. Evaluation of the role of endotoxin and cortisol on modulation of CD18 adhesion receptors in cows with mastitis caused by Escherichia coli. Am. J. Vet. Res. 60:534-540.

Sartorelli, P., S. Paltrinieri, and F. Agnes. 1999. Non-specific immunity and ketone bodies. I: In vitro studies on chemotaxis and phagocytosis in ovine neutrophils. J. Vet. Med. A. 46:613-619.

Sartorelli, P., S. Paltrinieri, and S. Comazzi. 2000. Non-specific immunity and ketone bodies. II: in vitro studies on adherence and superoxide anion production in ovine neutrophils. J. Vet. Med. A. $47: 1-8$

Scalia, D., N. Lacetera, U. Bernabucci, K. Demeyere, L. Duchateau, and C. Burvenich. 2006. In vitro effects of nonesterified fatty acids on bovine neutrophils oxidative burst and viability. J. Dairy Sci. 89:147-154.

Schalm, O. W., E. J. Carroll, and J. Lasmanis. 1964a. The leukocyte barrier and serologic investigations of experimental coliform (Aerobacter aerogenes) mastitis in cattle. Am. J. Vet. Res. 25:90-96.

Schalm, O. W., J. Lasmanis, and E. J. Carroll. 1964b. Effects of pre-existing leukocytosis on experimental coliform (Aerobacter aerogenes) mastitis in cattle. Am. J. Vet. Res. 25:83-96.

Schalm, O. W., J. Lasmanis, and E. J. Carroll. 1966. Significance of leukocytic infiltration into the milk in experimental Streptococcus agalactiae mastitis in cattle. Am. J. Vet. Res. 27:1537-1546.

Schanbacher, F. L., R. E. Goodman, and R. S. Talhouk. 1993. Bovine mammary lactoferrin: Implications from messenger ribonucleic acid (mRNA) sequence and regulation contrary to other milk proteins. J. Dairy Sci. 76:3812-3831.

Schmitz, S., M. W. Pfaffl, H. H. D. Meyer, and R. M. Bruckmaier. 2004 Short-term changes of mRNA expression of various inflammatory factors and milk proteins in mammary tissue during LPS-induced mastitis. Domest. Anim. Endocrinol. 26:111-126.

Schumann, R. R., and E. Latz. 2000. Lipopolysaccharide-binding protein. Chem. Immunol. 74:42-60.

Shafer-Weaver, K. A., G. M. Pighetti, and L. M. Sordillo. 1996. Diminished mammary gland lymphocyte functions parallel shifts in trafficking patterns during the postpartum period. Proc. Soc. Exp. Biol. Med. 212:271-279.

Shafer-Weaver, K. A., and L. M. Sordillo. 1997. Bovine CD8+ suppressor lymphocytes alter immune responsiveness during the postpartum period. Vet. Immunol. Immunopathol. 56:53-64.

Shuster, D. E., and M. E. Kehrli Jr. 1995. Administration of recombinant human interleukin 1 receptor antagonist during endotoxininduced mastitis in cows. Am. J. Vet. Res. 56:313-320.

Shuster, D. E., M. E. Kehrli Jr., and C. R. Baumrucker. 1995. Relationship of inflammatory cytokines, growth hormone, and insulin- 
like growth factor-I to reduced performance during infectious disease. Proc. Soc. Exp. Biol. Med. 210:140-149.

Shuster, D. E., M. E. Kehrli Jr., P. Rainard, and M. J. Paape. 1997. Complement fragment $\mathrm{C} 5 \mathrm{a}$ and inflammatory cytokines in neutrophil recruitment during intramammary infection with Escherichia coli. Infect. Immun. 65:3286-3292.

Shuster, D. E., M. E. Kehrli Jr., and M. G. Stevens. 1993. Cytokine production during endotoxin-induced mastitis in lactating dairy cows. Am. J. Vet. Res. 54:80-85.

Shuster, D. E., E.-K. Lee, and M. E. Kehrli Jr. 1996. Bacterial growth, inflammatory cytokine production, and neutrophil recruitment during coliform mastitis in periparturient versus midlactation cows. Am. J. Vet. Res. 57:1569-1575.

Smith, K. L., and F. L. Schanbacher. 1977. Lactoferrin as a factor of resistance to infection of the bovine mammary gland. J. Am. Vet. Med. Assoc. 15:1224-1227.

Smith, K. L., D. A. Todhunter, and P. S. Schoenberger. 1985a. Environmental mastitis: Cause, prevalence, prevention. J. Dairy Sci. 68:1531-1553.

Smith, K. L., D. A. Todhunter, and P. S. Schoenberger. 1985b. Environmental pathogens and intramammary infection during the dry period. J. Dairy Sci. 68:402-417.

Sordillo, L. M., M. J. Redmond, M. Campos, L. Warren, and L. A. Babiuk. 1991. Cytokine activity in bovine mammary gland secretions during the periparturient period. Can. J. Vet. Res. 55:298-301.

Speirs, V., P. J. Carder, S. Lane, D. Dodwell, M. R. J. Lansdown, and H. M. Hanby. 2004. Oestrogen receptor: What it means for patients with breast cancer. Lancet Oncol. 5:174-181.

Sumby, P., K. D. Barbian, D. J. Gardner, A. R. Whitney, D. M. Welty, R. D. Long, J. R. Bailey, M. J. Parnell, N. P. Hoe, G. G. Adams, F. R. Deleo, and J. M. Musser. 2005. Extracellular deoxyribonuclease made by group A Streptococcus assists pathogenesis by enhancing evasion of the innate immune response. Proc. Natl. Acad. Sci. USA 102:1679-1684.

Suriyasathaporn, W., A. J. J. M. Daemen, E. N. Noordhuizen-Stassen, S. J. Dieleman, M. Nielen, and Y. H. Schukken. 1999. $\beta$-Hydroxybutyrate levels in peripheral blood and ketone bodies supplemented in culture media affect the in vitro chemotaxis of bovine leukocytes. Vet. Immunol. Immunopathol. 68:177-186.

Taylor, M. J., M. E. Kehrli Jr., and E.-K. Lee. 2002. Bovine tumor necrosis factor receptor- 1 and methods of use. Iowa State University Research Foundation; USDA, assignees. US Patent No. $6,406,907$.

Taylor, M. J., M. E. Kehrli Jr., E.-K. Lee, and S. Mwangi. 2005. Bovine tumor necrosis factor receptor-1 and methods of use. Iowa State University Research Foundation; USDA, assignees. US Patent No. 6,939,950.

Thomas, C. J., M. Kapoor, S. Sharma, H. Bausinger, U. Zyilan, D. Lipsker, D. Hanau, and A. Surolia. 2002. Evidence of a trimolecular complex involving LPS, LPS binding protein and soluble CD14 as an effector of LPS response. FEBS Lett. 531:184-188.

Tobias, P. S., R. I. Tapping, and J. A. Gegner. 1999. Endotoxin interactions with lipopolysaccharide-responsive cells. Clin. Infect. Dis. 28:476-481.

van Amersfoort, E. S., T. J. Van Berkel, and J. Kuiper. 2003. Receptors, mediators, and mechanisms involved in bacterial sepsis and septic shock. Clin. Microbiol. Rev. 16:379-414.

Vandeputte-Van Messom, G. V., and C. Burvenich. 1993. Effect of somatotropin on changes in milk production and composition dur- ing coliform mastitis in periparturient cows. J. Dairy Sci. 76:3727-3741.

Vandeputte-Van Messom, G., C. Burvenich, E. Roets, A. M. MassartLeën, R. Heyneman, W. D. Kremer, and A. Brand. 1993. Classification of newly calved cows into moderate and severe responders to experimentally induced Escherichia coli mastitis. J. Dairy Res. 60:19-29.

Vangroenweghe, F., L. Duchateau, and C. Burvenich. 2004a. Moderate inflammatory reaction during experimental Escherichia coli mastitis in primiparous cows. J. Dairy Sci. 87:886-895.

Vangroenweghe, F., I. Lamote, and C. Burvenich. 2005. Physiology of the periparturient period and its relation to severity of clinical mastitis. Domest. Anim. Endocrinol. 29:283-293.

Vangroenweghe, F., P. Rainard, M. J. Paape, L. Duchateau, and C. Burvenich. 2004b. Increase of Escherichia coli inoculum doses induces faster innate immune response in primiparous cows. J. Dairy Sci. 87:4132-4144.

Van Merris, V., E. Meyer, L. Duchateau, and C. Burvenich. 2004. Differential effects of steroids and retinoids on bovine myelopoiesis in vitro. J. Dairy Sci. 87:1188-1195.

Van Oostveldt, K., F. Vangroenweghe, H. Dosogne, and C. Burvenich. 2001. Apoptosis and necrosis of blood and milk polymorphonuclear leukocytes in early and midlactating healthy cows. Vet. Res. $32: 617-622$

van Werven, T., E. N. Noordhuizen-Stassen, A. J. Daemen, Y. H. Schukken, A. Brand, and C. Burvenich. 1997. Preinfection in vitro chemotaxis, phagocytosis, oxidative burst, and expression of CD11/CD18 receptors and their predictive capacity on the outcome of mastitis induced in dairy cows with Escherichia coli. J. Dairy Sci. 80:67-74.

Viriyakosol, S., J. C. Mathison, P. S. Tobias, and T. N. Kirkland. 2000. Structure-function analysis of CD14 as a soluble receptor for lipopolysaccharide. J. Biol. Chem. 275:3144-3149.

Wall, R. J., A. M. Powell, M. J. Paape, D. E. Kerr, D. D. Bannerman, V. G. Pursel, K. D. Wells, N. Talbot, and H. W. Hawk. 2005. Genetically enhanced cows resist intramammary Staphylococcus aureus infection. Nat. Biotechnol. 23:445-451.

Weber, P. S., S. A. Madsen, G. W. Smith, J. J. Ireland, and J. L. Burton. 2001. Pre-translational regulation of neutrophil L-selectin in glucocorticoid- challenged cattle. Vet. Immunol. Immunopathol. 83:213-240.

Weber, P. S., T. Toelboell, L. C. Chang, J. D. Tirrell, P. M. Saama, G. W. Smith, and J. L. Burton. 2004. Mechanisms of glucocorticoidinduced down-regulation of neutrophil L-selectin in cattle: Evidence for effects at the gene-expression level and primarily on blood neutrophils. J. Leukoc. Biol. 75:815-827.

Wenz, J. R., G. M. Barrington, F. B. Garry, K. D. McSweeney, R. P. Dinsmore, G. Goodell, and R. J. Callan. 2001. Bacteremia associated with naturally occuring acute coliform mastitis in dairy cows. J. Am. Vet. Med. Assoc. 219:976-981.

Wetteman, R. P. 1980. Postpartum endocrine function of cattle, sheep and swine. J. Anim. Sci. 51:2-11.

Yang, T. J., I. A. Ayoub, and M. J. Rewinski. 1997. Lactation stagedependent changes of lymphocyte subpopulations in mammary secretions: Inversion of CD4+/CD8+ T cell ratios at parturition. Am. J. Reprod. Immun. 37:378-383.

Yarus, S., J. M. Rosen, A. M. Cole, and G. Diamond. 1996. Production of active bovine tracheal antimicrobial peptide in milk of transgenic mice. Proc. Natl. Acad. Sci. USA 93:14118-14121.

Yates, J. R. 2004. Mass spectral analysis in proteomics. Annu. Rev. Biophys. Biomol. Struct. 33:297-316. 